\title{
ROZWÓJ FORMUŁ MELODYCZNYCH W STARORUSKIEJ MONODII CERKIEWNEJ NA PRZYKŁADZIE DOGMATYKA TONU DRUGIEGO NA PODSTAWIE WYBRANYCH ZACHODNIORUSKICH IRMOLOGIONÓW XVI-XVIII W.
}

Staroruski śpiew cerkiewny od dawien dawna wzbudza zainteresowanie badaczy, w szczególności teologów, muzykologów oraz ekspertów w dziedzinie sztuki. Niestety wiele jego ważnych aspektów jak dotąd nie doczekało się należytego opracowania. Do takich z całą pewnością należą tradycje śpiewacze praktykowane przez Cerkiew prawosławną, zaś od 1596 r. także unicką, na terytoriach Wielkiego Księstwa Litewskiego i Rzeczypospolitej. To właśnie pilna potrzeba wypełnienia luk istniejących w obecnym stanie wiedzy skłoniła mnie do podjęcia szerszych badań nad formami śpiewu cerkiewnego funkcjonującymi na tych terenach, ze szczególnym uwzględnieniem prawosławnej eparchii przemyskiej oraz unickiej diecezji włodzimiersko-brzeskiej. W obydwu diecezjach, a także w diecezji chełmskiej rozwijały się tradycje monodycznego śpiewu cerkiewnego, odznaczające się bogactwem form. Niniejsze opracowanie jest kolejnym etapem moich badań nad staroruskim śpiewem cerkiewnym i jego funkcjonowaniem w wyżej wymienionych eparchiach, a nade wszystko w prawosławnej eparchii przemyskiej'. Dotychczas prowadzone

Dr DANIEL SAWICKI - doktor nauk teologicznych, obecnie doktorant w Instytucie Historii UMCS, historyk, badacz staroruskiego śpiewu cerkiewnego; e-mail: infoechos@wp.pl

DANIEL SAWICKI, $\mathrm{PhD}$ - doctor of theological sciences, currently a PhD student at the Institute of History of UMCS, historian, researcher of Old Ruthenian Orthodox Church singing; e-mail address: infoechos@wp.pl

${ }^{1}$ D. SAwICKI, Staroruski neumatyczny Irmologion Lawrowski z XVI wieku - niezbadany zabytek wschodniosłowiańskiego piśmiennictwa muzycznego na południowo-zachodniej Rusi, „Wschodni Rocznik Humanistyczny” 13(2016), [Lublin-Radzyń Podlaski], s. 18-56; System formuł melodycznych 
przeze mnie badania miały głównie charakter porównawczy², z uwzględnieniem wszystkich form śpiewu zawartych w znajdujących się w polskich zbiorach zabytkach pisanych staroruską notacją kriukową oraz kwadratową notacją kijowską.

Kluczową rolę w rozwoju staroruskiego śpiewu cerkiewnego zarówno wyżej wymienionych, jak i pozostałych w prawosławnych eparchiach metropolii kijowskiej odegrały monastery. Wśród ośrodków monastycznych, znajdujących się w obrębie dawnej eparchii przemyskiej, na pierwszy plan wysuwa się monaster św. Onufrego w Ławrowie, skąd pochodzi datowany na drugą poł. XVI w. Irmologion ${ }^{3}$ Ławrow$\mathrm{ski}^{4}$. Równie istotną rolę w dziejach śpiewu cerkiewnego na południowo-zachodniej Rusi odegrał monaster Zwiastowania N.M.P. w Supraślu, gdzie w latach 15981601 Bogdan Onisimowicz z Pińska zredagował swój monumentalny Irmologion ${ }^{5}$. Doskonale zachowany kodeks stanowi istotne źródło do badań porównawczych, w szczególności ze źródłami pisanymi notacją kriukową.

Wraz z zawarciem w 1596 r. Unii brzeskiej oraz powołaniem do życia zakonu bazylianów diametralnie spada rola monasterów jako ośrodków rozwoju śpiewu cerkiewnego na południowo-zachodniej Rusi. Z czasem ich miejsce zajmą poszczególne parafie, i to zarówno prawosławne, jak i unickie. Mimo nasilających się tendencji zmierzających do latynizacji obrządku unickiego to właśnie parafie zachowały bogate tradycje monodycznego śpiewu cerkiewnego, który dla prostego ludu był o wiele bardziej przystępny i zrozumiały, aniżeli komponowane w oparciu o wzorce zachodnie śpiewy wielogłosowe. Dobrym przykładem ośrodków parafialnych, które po synodzie zamojskim 1720 r. były nieustannie poddawane proce-

staroruskiego śpiewu cerkiewnego na przykładzie dogmatyka tonu pierwszego z XVI-wiecznego Irmologionu Ławrowskiego, „Wschodni Rocznik Humanistyczny” 16(2017), nr 1, s. 7-28.

${ }^{2}$ TenżE, Ciagłość tradycji staroruskiej monodii cerkiewnej na przykładzie wybranych dogmatyków ośmiu skal modalnych z Irmologionów Lawrowskiego i Supraskiego „Wschodni Rocznik Humanistyczny" 15(2018), nr 1, s. 23-50.

${ }^{3}$ Irmologion - cs. Księga liturgiczna zawierająca w sobie irmosy, tj. pieśni z Oktoicha, śpiewane m.in. podczas jutrzni. Całość materiału podzielona jest na 8 skal modalnych (cs. głasow). Księga zajmuje ważne miejsce w liturgii staroobrzędowców. Е. ГригорьЕв, Пособие по изучению иерковного пения и чтения, Рига 2001, s. 311; por. Г. АЛЕкСеввА, Византино-русская певческая палеография, Санкт-Петербург 2007, s. 323. Z biegiem czasu do Irmologionu zaczęto dodawać inne śpiewy nabożeństw Całonocnego Czuwania oraz Świętej Liturgii, czego przykładem jest tzw. Irmologion Supraski. Zob.: W. WoŁosiuk, Irmologion Supraski, „Rocznik Teologiczny” 66(2004), nr 2; M. ABIJSKi, Bogdan Onisimowicz - śpiewak rodem z Pińska, „Latopisy Akademii Supraskiej”, vol. 1: Prawosławni w dziejach Rzeczypospolitej, Białystok 2010, s. 49-58.

${ }^{4}$ Biblioteka Narodowa w Warszawie, sygn. Rps 12050 ( Akc 2954).

${ }^{5}$ Centralna Naukowa Biblioteka im. Wernadskiego - Kijów, ЦНБ, sygn I, 5391, por. Ю. ЯСІновський, Супрасльский ірмолой Богдана Онисимовича як пам'ятка київської митрополії, „КАИОФQNIA” 8(2016), s. 46-88. 
sowi latynizacji, a mimo to zachowały unikatowe tradycje śpiewu cerkiewnego, są parafie unickie znajdujące się na terytoriach eparchii włodzimiersko-brzeskiej oraz chełmskiej, w szczególności usytuowane na Południowym Podlasiu. Materialnym świadectwem profesjonalizmu śpiewu liturgicznego, praktykowanego na tych terenach, są nielicznie zachowane irmologiony. Niestety wskutek kasaty unii w 1875 r. oraz burzliwych wydarzeń, jakie temu towarzyszyły, wiele cennych śpiewników uległo bezpowrotnemu zniszczeniu, a praktykowane od wieków melodie uległy stopniowemu zapomnieniu. Mimo to do naszych czasów przetrwało kilka irmologionów pochodzących z XVII i XVIII w., w szczególności śpiewniki z cerkwi unickich w Rokitnie oraz Witorożu, które są materialnym świadectwem głębokiego przywiązania miejscowych śpiewaków do „tradycji ojców”, mimo stale nasilających się tendencji latynizacyjnych obrządku unickiego na tych terenach ${ }^{6}$.

Na szczególną uwagę zasługują staroruskie melodie dogmatyków ośmiu skal modalnych (in. tonów, cs. głasow). Ze względu na bogactwo treści teologicznej, dogmatyki stanowią szczególny gatunek hymnografii prawosławnej. W tekstach dogmatyków św. Jan z Damaszku dokonał wyjaśnienia głównych prawd wiary (m.in. Wcielenia Syna Bożego, dwóch natur w Chrystusie oraz dogmatu o Bogurodzicy) ${ }^{7}$. Omówienie wszystkich ośmiu dogmatyków niewątpliwie przekroczyłoby ramy niniejszego opracowania, dlatego skupimy uwagę na dogmatyku tonu drugiego, w którym św. Jan z Damaszku wyjaśnił związki łączące wydarzenia starotestamentalne $\mathrm{z}$ nowotestamentowymi ${ }^{8}$. Na przykładzie melodii dogmatyka tonu drugiego, zaczerpniętej z Irmologionu Ławrowskiego, a także poprzez porównania jej z innymi późniejszymi zabytkami, zostanie ukazany paralelizm w zastosowaniu formuł melodycznych (popiewek, lic i fit), które odpowiednio dobrane stanowią logiczny ciąg niejako komentujący treść dogmatyka, jaką są dzieje zbawienia. Pod pojęciem popiewki należy rozumieć określoną formułę melodyczną, posiadającą własną pisownię oraz wynikające z tworzących ją znaków jasno określone zasady wykonawcze9. Bizantyjskim odpowiednikiem określenia popiewka jest funkcjonujące w wielu traktatach teoretycznych określenie. melodema (gr. $\tau$ ò $\mu \varepsilon \lambda o ́ \delta \eta \mu \alpha)^{10}$.

${ }^{6}$ D. Sawicki, Z badań nad śpiewem cerkiewnym na Poludniowym Podlasiu w XVIII-XIX w. Irmologiony z Rokitna i Witoroża, ,Rocznik Bialskopodlaski” [Biała Podlaska] 24(2016), s. 89-117.

${ }^{7}$ Н. Флоринский, История богослужебных песнопений Православной Кафолической Восточной Церкви, Kijów 1881, s. 170.

${ }^{8}$ D. SAwicki, System formut melodycznych, s. 16.

${ }_{9}^{9}$ А. Кручинина, О семиографии попевок знаменного роспева в музыкально-теоретических руководствах нониа XV - середины XVII века, w: Проблемы истории и теории древнерусской музыки, сост. А Белоненко, Ленинград 1979, s. 148-159.

${ }^{10}$ Е. Лозовая, Столповой знаменный распев (2-я половина (XV-XVII вв.) Формульная структура, Москва 2015, s. 5. 
Większość popiewek znamiennago raspiewa mimo upływu czasu zachowała swoją pierwotną pisownię, co znacząco ułatwia ich identyfikację i interpretację ${ }^{11}$. Z biegiem lat pod pojęciem popiewki zaczęto także rozumieć bardziej złożone pod względem melodycznym kompozycje ${ }^{12}$. Twórcy staroruskich melodii cerkiewnych traktowali popiewkę jako jedną logiczną całość ${ }^{13}$. Podobny punkt widzenia wykształcił się także w Bizancjum, gdzie pod wpływem reform notacji, jakie dokonały się ok. XII w., (każdy ton (gr. ̃̃ $\chi \varsigma$ ) zaczęto postrzegać nie jako zbiór następujących po sobie dźwięków, lecz jako zbiór określonych formuł melodycznych ${ }^{14}$. W dogmatyku tonu drugiego występują także formuły melodyczne melizmatycznego charakteru, w szczególności fity.

Tekst liturgiczny dogmatyka tonu drugiego tak z Irmologionu Ławrowskiego, jak również z Irmologionu Supraskiego (1598-1601) zawiera typowe dla piśmiennictwa muzycznego tego okresu elementy „razdielnorieczija” in. chomonii. Chodzi o manierę wykonawczą, polegającą na zamianie wymowy [o] lub [e] w miejscach tzw. jerów oznaczonych literami ъ i b ${ }^{15}$. Początki „,razdielnorieczija” sięgają na Rusi końca XIV wieku ${ }^{16}$. Zastępowanie spółgłosek samogłoskami wynikało z faktu, że kopiści (od końca XIV w.) poczęli umieszczać znaki muzyczne nad spółgłoskami znajdującymi się w końcu wyrazu, których wykonanie było z wielu względów niemożliwe ${ }^{17}$.

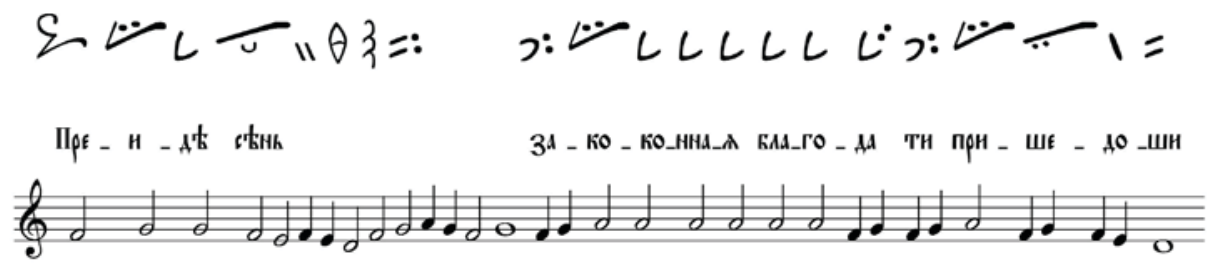

${ }^{11}$ А. Кручинина, О семиографии, s. 149.

${ }^{12}$ ТА⿱̇, Попевка знаменного роспева в русской музыкальной теории, w: Певческое наследие Древней Руси (историа, теория, эстетика), Санкт-Петербург 2002, s. 52.

${ }_{13}^{13}$ В. МАртынов, История богослужсебного пения, Москва 1994, s. 122.

${ }^{14}$ Е. ГерцмАн, Византийское музыкознание, Ленинград 1988, s. 197.

${ }^{15}$ Б. УСпенский, К вопросу о хомовом пении, w: Музыкальная культура средневековья, Вып. 2, (Тезисы и доклады конференций), Москва 1991, s. 144.

${ }^{16}$ D. SAWICKI, Nauczanie staroobrzędowców pomorskich w kwestiach odnoszacych się do śpiewu cerkiewnego, ELPIS 19(2017), s. 69.

${ }^{17}$ D. SAWICKI, Staroje istinnorieczije i razdielnorieczije jako dwie główne epoki w dziejach śpiewu liturgicznego na Rusi od XI w. do XVII w., w: Z badań nad językiem i kultura Stowian, red. P. Sotirov, P. Złotkowski, Lublin 2007, s. 169. 
„Przeminął cień Zakonu, gdy nadeszła łaska”, ten jakże krótki, a mimo to bardzo wymowny fragment dogmatyka tonu drugiego jest swoistym streszczeniem całej jego treści. Pod pojęciem Zakonu, który przeminął, aby nadszedł czas łaski hymnograf rozumiał całe Prawo starotestamentalne, które Bóg dał narodowi wybranemu przez Mojżesza. Prawu, które swoim zasięgiem obejmowało wszystkie dziedziny życia Izraelitów, od moralnego, poprzez obrzędowość, a na prawodawstwie państwowym skończywszy, hymnograf przeciwstawia Łaskę, która zakrólowała wraz z przyjściem na świat Syna Bożego - Jezusa Chrystusa. Stąd wypływa cała treść i kompozycja dogmatyka, której istota tkwi w przedstawieniu wydarzeń starotestamentalnych w kontekście ich wypełnienia się w Nowym Testamencie ${ }^{18}$.

Treść dogmatyka wymagała zastosowania odpowiednich formuł melodycznych: popiewek, lic i fit. W miejscach, gdzie tekst liturgiczny odwołuje się do wydarzeń starotestamentalnych, twórcy staroruskich melodii cerkiewnych zwykli stosować bardziej rozbudowane melodycznie popiewki, a niekiedy także lica i fity, co w przypadku dogmatyka tonu drugiego miało symbolizować okres tysięcy lat, jakie upłynęły od upadku prarodziców Adama i Ewy do przyjścia na Świat Zbawiciela. Fity, których znajomość ze względu na bardzo złożoną melodykę postrzegano jako szczególną mądrość filozoficzną, symbolizują mnogość przepisów Prawa Mojżeszowego. Jak wiemy, ich literalne wypełnianie z czasem doprowadziło Izrael do stanu swoistej „niewoli Prawa”"19. Wiedzę o fitach, ze względu na jej sakralny charakter, dane było poznać jedynie wybranym ${ }^{20}$, tak samo jak Syn Boży objawił się najpierw pasterzom betlejemskim, a następnie trzem mędrcom ze Wschodu, świat bowiem był wtedy zajęty własnymi sprawami. Cały Stary Testament przygotowywał Izrael na nadejście „czasu łaski”, która objawiła się w Osobie Jezusa Chrystusa. W ten jakże krótki, a mimo to wymowny fragment dogmatyka tonu drugiego staroruski kompozytor wprowadza za pomocą formuły melodycznej o nazwie opoczinka, którą poprzedza recytatywne wprowadzenie. Za dawnością tradycji śpiewu, zawartej w Irmologionie Eawrowskim przemawia fakt, iż tekst liturgiczny dogmatyka tonu drugiego, mimo obecności chomonii, zawiera pozostałości po „starej mowie prawdziwej”, obecnej w piśmiennictwie muzycznym na Rusi do końca XIV w. Dobrym przykładem przenikania obydwu tradycji jest słowo s'kн, które w Irmologionie Lawrowskim występuje w formie typowej dla okresu starej mowy prawdziwej, a ściślej

\footnotetext{
${ }^{18}$ С. БорЗецовский, Объяснение догматиков восьми гласов, Москва 1878, s. 25-27.

${ }^{19}$ Staroobrzędowe podręczniki do nauki śpiewu symbolikę fity interpretują jako: „Философиа истинное пребувание и любление ко всем вседушное, и дерзновение к Богу в молитве непостыдное”. Азбука певчая, ККГУНБ, № 76647, k. 15.

${ }^{20}$ Т. ВлАДЫШЕвскАя, Музыкальная культура древней руси, Москва 2006, s. 140.
} 
dla przełomu XIII-XIV w. Natomiast to samo słowo w Irmologionie Supraskim pojawia się w pisowni typowej dla okresu ,,razdielnorieczija”. Wskutek przesunięcia akcentacji r'kne na ostatnią sylabę doszło do rozrostu melizmatów ${ }^{21}$. Stąd naturalnym wydaje się zastosowanie przez redaktora formuły melizmatycznej, tj. lica lub fity. Omawiane zjawisko występuje zarówno w Irmologionie Supraskim, jak również w innych redakcjach, zarówno moskiewskich, jak też zachodnio-ruskich. Odrębną kwestią jest formuła melodyczna, jaką zastosował redaktor Irmologionu Ławrowskiego. Jako ciekawostkę można podać fakt, iż pod względem zawartości oraz niektórych cech paleograficznych Irmologion z Ławrowa jest bardzo podobny do dwóch Stichrerarow nr 410 i 414 ze zbiorów Ławry Troicko-Siergiejewskiej. Zarówno w Irmologionie Ławrowskim, jak również w Sticherare $\mathrm{nr} 410$ występuje fita zielnaja, która w melodii dogmatyka tonu drugiego posiada następującą pisownię $\widehat{v i t}\}=: 22$. Ta jakże rozbudowana melodycznie fita występuje w kilku wariantach pisowni w melodiach tonu drugiego i szóstego. Badacz staroruskiego śpiewu cerkiewnego przełomu XIX i XX w. - o. Bazyli Mietałłow - określa ją mianem lica-kokizy drugiego tonu ${ }^{23}$. W rękopisach XVII-wiecznych oraz późniejszych, powstałych na potrzeby staroobrzędowców, formuła ta występuje jako lico, przy czym pojawia się ona zarówno w wersji zaszyfrowanej jak i rozszyfrowanej ${ }^{24}$.

W niektórych zbiorach fit omawianą formułę przypisano także do tonu trzeciego, przy czym jej znaczenie muzyczne w tymże tonie jest zgoła inne ${ }^{25}$. Co ciekawe w załączonym do Irmologionu Ławrowskiego elementarzu neum fita zielnaja występuje $\mathrm{w}$ nieco odmiennej pisowni $=\pi \widetilde{\pi}=1=:$, bez znaku fity $\theta^{26}$. Począwszy od końca XVI w. w Irmologionach pisanych kwadratową notacją kijowską formuła ta przybiera nieco zmienioną formę. Dla zilustrowania zmian, jakie zaszły w jej melodyce na przestrzeni kilkudziesięciu lat, pozwolę sobie posłużyć się przykładami, zaczerpniętymi z Irmologionu Supraskiego (1598-1601) ${ }^{27}$ oraz datowanego na 1630 r. Irmologionu z Bruślinowa (diec. kijowska) ${ }^{28}$. O ile w przypadku motywu wprowadzającego, odpowiadającego słowu Ilpєнд'k , w Irmologionach Ławrowskim

${ }^{21}$ ЦНБ, sygn. I, 5391, k. 232.

${ }^{22}$ BN, Rps 12050 ( Akc 2954), k. 209.

${ }^{23}$ В. Металлов, Азбука крюкового пения. Опыт систематического руководства к чтению крюковой семиографии песнопений знаменного роспева, периода киноварных помет, Москва 1899 , s. 129 , poz. 43.

${ }^{24}$ Ирмолой и Октай, (2. poł. XVIII w., Zbiory prywatne Daniela Sawickiego), k.136, por. Октай (XIX w.), Zb. pryw. DS, k. 18.

${ }^{25}$ М. БРАЖников, Лица и фиты знаменного распева, Ленинград 1984, s. 186.

${ }^{26}$ BN, Rps 12050 ( Akc 2954), k. 259.

${ }^{27}$ ЦНБ, sygn. I, 5391.

${ }^{28}$ BN, 12055 I (Akc. 2932), k. 6. 
i Supraskim mamy pełną zgodność zapisu, gdzie linia melodyczna odpowiada trzem krótkim wartościom nutowym, wznoszącym się na odległość sekundy wielkiej.
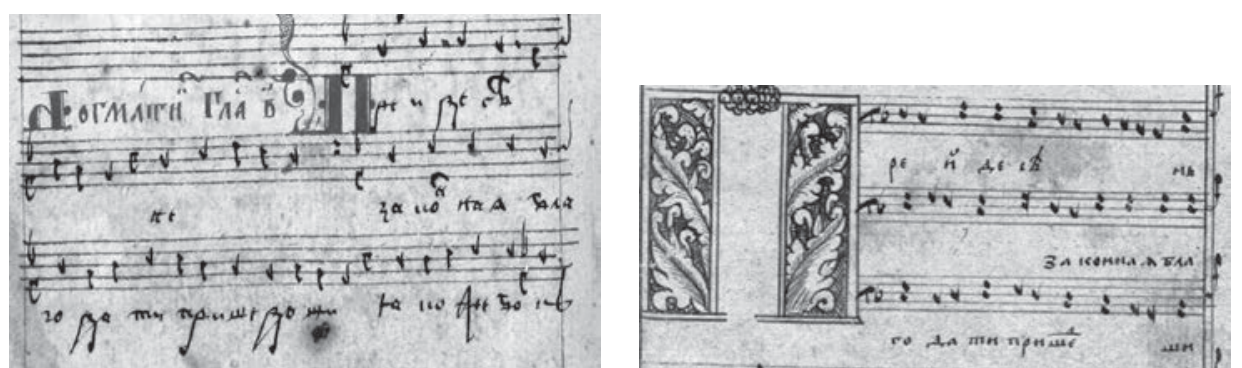

Rysunek 1.

Jak widzimy na powyższym przykładzie, redaktor Irmologionu z Bruślinowa zastosował opadający pochód sekundowy odpowiadający neumie stopica s oczkom $\llcorner$. Równie nietypowy, a jednocześnie bardzo interesujący sposób zapisu omawianego fragmentu dogmatyka tonu drugiego zastosował redaktor pochodzącego z końca XVII w. Irmologionu z cerkwi unickiej p.w. Świętej Trójcy i Podwyższenia Krzyża Świętego w Rokitnie (dek. Biała, diec. Brześć) ${ }^{29}$. Otóż redaktor dokonał zespolenia ze sobą dwóch sposobów zapisu. Z jednej strony dokonał przetransponowania melodii o sekundę wyżej w stosunku do wcześniejszych redakcji, zaś z drugiej strony powtarza motywy w skali durowej, co sygnalizuje umieszczając przed frazą znak chromatyczny, a ściślej bemol. Na pierwszy rzut oka może się wydawać, iż mamy tutaj do czynienia ze swoistą ,mutacją”, a ściślej ze zmianą skali dźwiękowej. Analogiczne zjawiska występują w wielu melodiach drugiej skali modalnej, na co zwracają uwagę uczeni ukraińscy, w szczególności Jurij Jasinowski ${ }^{30}$
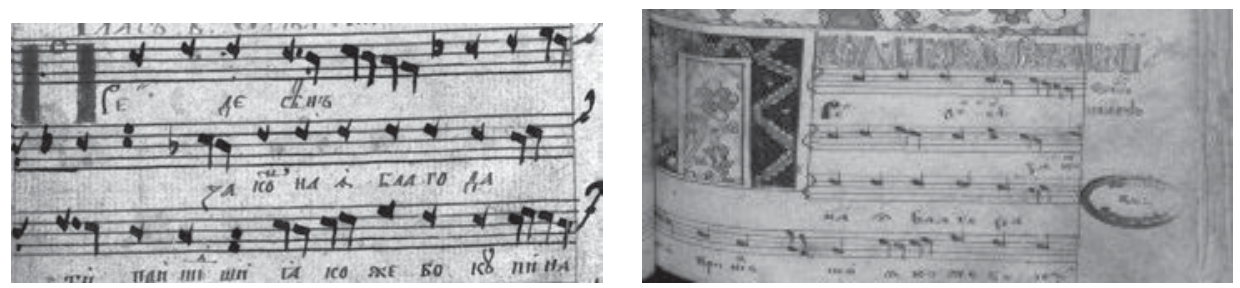

Rysunek 2.

\footnotetext{
${ }^{29}$ Katolicki Uniwersytet Lubelski Jana Pawła II, Rkp 387, k. 9.

${ }^{30}$ Ю. Яспновський, Ірмоси Київської Церкви. Критичне видання за супрасльским нотолінійним ірмологіоном 1598-1601 років, Т. II, Львів 2018, s. 345.
} 
Analogiczny zapis, lecz bez bemoli, znajdziemy w datowanym na drugą poł. XVIII w. Irmologionie, pochodzącym z cerkwi unickiej p.w. św. Michała Archanioła w Witorożu (dek. Biała, diec. Brześć) $)^{31}$. Już pobieżne porównanie obydwu zabytków pozwala twierdzić, iż redaktor Irmologionu z Rokitna popełnił błąd w zapisie. Być może starał się zapisać taką wersję melodii, jaką znał na pamięć, lecz nie mając dostatecznej wiedzy teoretycznej posiłkował się takimi sposobami zapisu, jakimi sam władał. W tym miejscu nasuwa się na myśl pytanie, jaki stopień przygotowania merytorycznego reprezentowali diacy pracujący na wiejskich parafiach unickich? Mimo iż większość diaków wywodziła się bądź to z ludu, bądź byli to synowie duchownych, to stopień ich wykształcenia był bardzo zróżnicowany. $Z$ reguły wiedzę niezbędną do sprawowania służby w cerkwi diacy zdobywali m.in. poprzez systematyczne uczestnictwo w codziennych nabożeństwach oraz od swoich poprzedników ${ }^{32}$. Bywali diacy dobrze znający tajniki śpiewu oraz czytania w języku cerkiewno-słowiańskim, jak również tacy, którzy nie umieli ani czytać, ani pisać, a mimo to posługiwali w cerkwi. Wizytujący poszczególne parafie dziekani wymagali od proboszczów, aby każda miała diaka „biegłego w śpiewach cerkiewnych”, lecz to, jakiego dana parafia posiadała diaka w znaczącej mierze zależało od zamożności parafian, bądź hojności fundatorów świątyni ${ }^{33}$. Wszędzie tam, gdzie brakowało diaków, funkcje tę sprawowali bądź to członkowie rodziny kapłańskiej, bądź sami wierni. Diak, jak słusznie zauważa Dorota Wereda, był przede wszystkim śpiewakiem cerkiewnym, zakrystianinem i dzwonnikiem, a jeśli posiadał odpowiednie kwalifikacje, nauczał katechizmu ${ }^{34}$.

Gdy fraza melodyczna zbliża się do miejsca, gdzie tekst liturgiczny odwołuje się do łaski, melodia dwukrotnie wznosi się, a następnie opada w pochodzie sekundowym, by spocząć na dźwięku d ${ }^{1}$, który w tym przypadku pełni rolę kadencji. Sposób przedstawiania tegoż fragmentu stopniowo zmienia wraz z pojawieniem się pierwszych przekładów melodii z notacji neumatycznej na kwadratową notację kijowską. Dobrym przykładem zmian, zachodzących w niektórych frazach melodycznych,

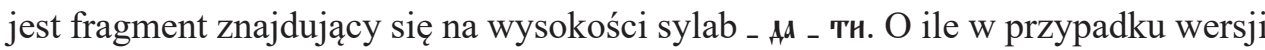
neumatycznej, zawartej w Irmologionie z Ławrowa, mamy do czynienia z dwoma następującymi po sobie pochodami sekundowymi $\iota_{\llcorner} \supset$ : których linia melodyczna wznosi się, o tyle już w Irmologionie Supraskim (1598-1601) oraz w Irmologionie

${ }^{31}$ KUL, Rkp 391, k. 59.

${ }^{32}$ D. SAwICKI, Z badań nad śpiewem, s. 100.

${ }^{33}$ D. WeREDA, Unicka diecezja włodzimiersko-brzeska (część brzeska) w XVIII w., Siedlce 2014, s. 110 .

${ }^{34}$ Tamże, s. 111. 
z Bruślinowa obserwuje się redukcję do jednego pochodu sekundowego tomiast w późniejszych redakcjach, a do takich z całą pewnością należą śpiewniki z Rokitna i Witoroża, widoczne jest nieznaczne przesunięcie akcentu na sylabę TH, której linia melodyczna opadając muły kadencji, która odpowiada słowu прншєдошн.

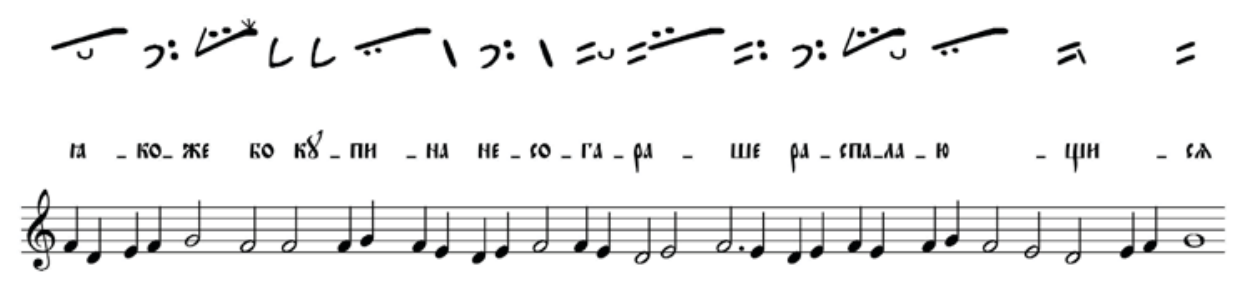

Przenajświętsza Bogurodzica Dziewica Maryja poczęła w Swoim dziewiczym łonie Syna Bożego Jezusa Chrystusa za sprawą Świętego Ducha. Syn Boży przyjął od Niej ludzką naturę, wolną od grzechu. W kolejnym fragmencie dogmatyka hymnograf przywołuje wydarzenie opisywane w księdze Wyjścia (Wj 3,2-3), gdzie Bóg objawił się Mojżeszowi pod postacią krzewu gorejącego, który nieustannie płonął, a mimo to nie uległ spaleniu. Bóg, obecny w krzewie, objawił się jako Władca Wszechrzeczy, Który ma nieograniczoną moc, aby zmieniać siły przyrody. W tym miejscu melodia przybiera bardziej swobodny charakter, gdzie dominują krótkie wartości nutowe. Kompozytor trzyma się sztywnych norm kompozycji, przez co bez trudu dostrzeżemy aż trzy popiewki stanowiące jej właściwy trzon, zaś we fragmencie mówiącym o krzewie gorejącym kompozytor zastosował kompozycję kulizmy + podjezd. Natomiast dla podkreślenia faktu, iż ów krzew, mimo iż płonął, to nie ulegał spaleniu, kompozytor umiejętnie wplata popiewkę mierieża s' podjemom, gdzie w końcu frazy linia melodyczna dynamicznie wznosi się ku górze, by ostatecznie spocząć na dźwięku g².

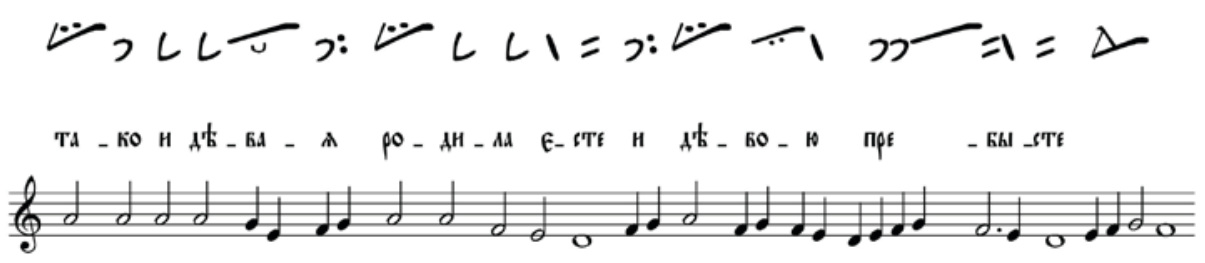


Ów krzew gorejący był dla Ojców Cerkwi praobrazem Łona Przenajświętszej Dziewicy Bogurodzicy, która poczęła i porodziła Syna Bożego, a mimo to Jej dziewictwo nie uległo naruszeniu. Tę odwieczną prawdę staroruski kompozytor zilustrował za pomocą umiejętnej kombinacji popiewek. Frazę rozpoczyna popiewka drugiego tonu-opoczinka. Natomiast we fragment tekstu, mówiący o dziewictwie Maryi, kompozytor wplótł dość skomplikowaną pod względem melodyki i pisowni formułę, tj. chrabricu s pałkom wielikim. W Irmologionie Supraskim omawiany fragment dogmatyka tonu drugiego posiada następującą melodię.

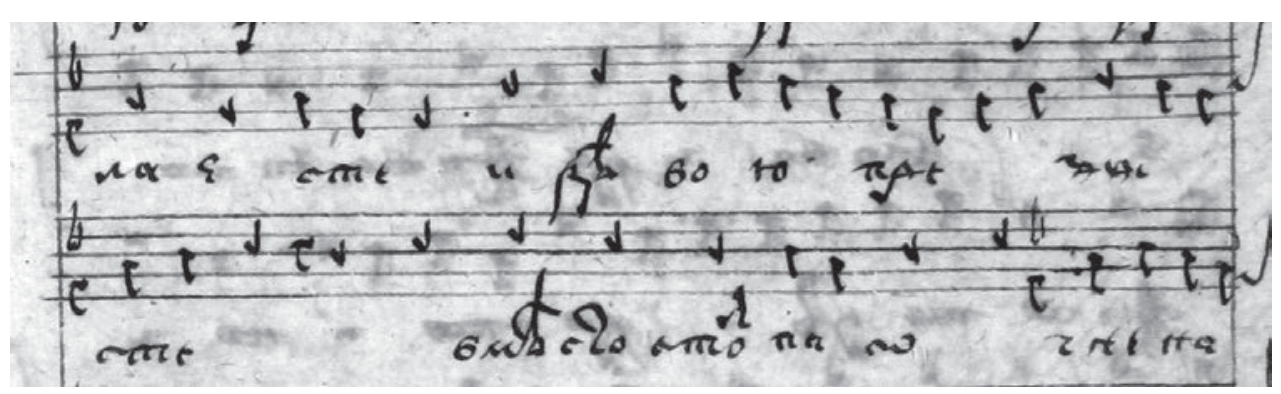

Rysunek 3.

Na właściwą formułę składają się znaki: skamiejca i pałka T, które pełnią tutaj rolę wprowadzenia (cs. podwod), a następnie wskutek zastosowanej kombinacji znaków striety gromnoj oraz potukulizmy » wznosi się, a następnie stopniowo opada w pochodzie sekundowym. Całość kompozycji dopełnia obecność melizmatu pauk wielikij $\Delta$, którego melodia symbolizuje nieskończoność oraz trudność do ogarnięcia przez rozum ludzkiej prawdy o „Zawszediewictwie” Matki Bożej. Jego pisownia na przestrzeni wieków przedstawia się następująco: a) $=\boldsymbol{\gamma}-\mathrm{XV} \mathrm{w} \cdot{ }^{35}$ b) $\boldsymbol{\nu}-\mathrm{XVI}$-XVII i XIX w. ${ }^{36}$ Już pierwsze Azbuki-pierieczislienija ściśle rozróżniają obydwie formuły, co każe przypuszczać, iż miały one także inne znaczenie muzyczne, które teoretycy znamiennago raspiewa nakazują wykonywać w ten oto sposób: Niekiedy pauk wielikij można spotkać także w następującej kombinacji: ${ }^{37}$, czego przykładem jest omawiany fragment dogmatyka tonu drugiego. Zastosowanie znaku pauk wielikij w tym konkretnym fragmencie dogmatyka tonu drugiego nie byłoby możliwe, gdyby nie chomonia tekstu liturgicznego, gdzie zamiast słowa прєьыТь redaktor umieścił прєЕыстє.

\footnotetext{
35 Д. ШАБАлин, Певческие азбуки Древней Руси, Т. І., Краснодар 2003, s. 8.

${ }^{36}$ Азбука певчая, НИОР РГБ, zеsp. 173.ІІІ., nr 151, k. 27.

${ }^{37}$ В. МетАллов, Азбука крюкового, s. 28.
} 

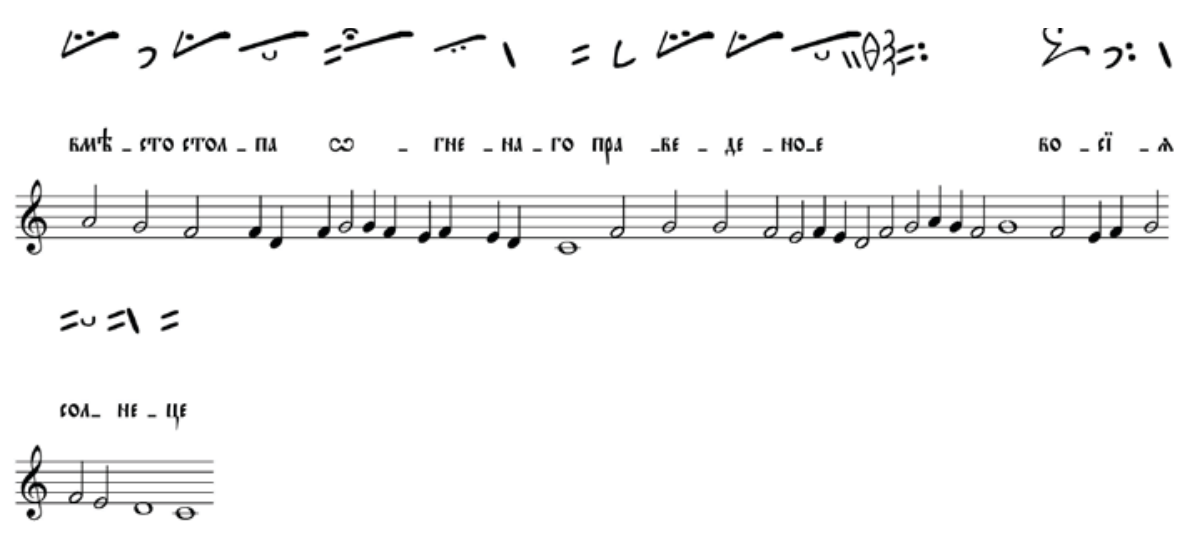

W słupie ognistym objawił się Bóg Mojżeszowi, słup ognisty oświecał także drogę Izraelitów do ziemi obiecanej, przez co mogli kontynuować ją nocą (por. Wj 13,21; 14,20). Słup ognisty wskazywał także kierunek, którym Naród Wybrany winien podążać, i tylko ta droga pozwoliła mu dotrzeć do celu. W tym fragmencie dogmatyka tonu drugiego św. Jan z Damaszku wskazuje, iż ów słup ognia był praobrazem „Słońca Prawdy” oraz Światłości świata, którą jest Syn Boży Jezus Chrystus, Który w Ewangelii według św. Jana mówi o sobie: „Ja jestem światłością świata. Kto idzie za Mną, nie będzie chodził w ciemności, lecz będzie miał światło życia" (J 8,12). Nauka Zbawiciela rozwiewa ciemności i mroki grzechu, a jednocześnie daje możliwość jasnego widzenia i prawidłowego zrozumienia zarówno prawd Bożych, jak elementów otaczającego świata ${ }^{38}$. Staroruski kompozytor stara się przeciwstawić obraz słupa ognistego, który oświetlał drogę Izraelitom, a który przeminął niegasnącemu Słońcu Sprawiedliwości, którym jest Jezus Chrystus, jak słyszymy w troparionie ${ }^{39}$ Jego Narodzenia. Pierwszy motyw nakreślają znak strieły $s$ obłaczkom = Oraz popiewka, której melodyka przypomina mierieżu s'riedniuju. Jej linia melodyczna wznosi się, a następnie dynamicznie opada w pochodzie sekundowym, by ostatecznie spocząć na dźwięku c $\mathrm{c}^{1}$, co oznacza zakończenie pewnego etapu w historii zbawienia - tj. etapu Starego Przymierza. Czasy Nowego Przymierza, które będą trwały aż do skończenia świata, symbolizuje fita zielnaja, która pojawia się po raz kolejny. W miejscu, gdzie hymnograf opiewa Jezusa

\footnotetext{
${ }^{38}$ C. Борзецовский, Объяснение, s. 30-31.

${ }^{39}$ Troparion (cs. Tropar') - pieśń (hymn) liturgiczna stanowiąca wykładnię istoty święta lub obchodzonego przez Kościół wydarzenia bądź przedstawiająca wydarzenia zaczerpnięte z Żywota Świętego; z troparionów zbudowane są pieśni Kanonów. Cyt. za: A. Znosko, Stownik cerkiewnostowiańsko-polski, Białystok 1996, s. 351.
} 
Chrystusa - Słońce Sprawiedliwości, linia melodyczna dynamicznie wznosi się w pochodzie sekundowym, przy czym fragment melodii odpowiadający słowu korï (tłum. zajaśniało) pełni rolę wprowadzenia do właściwego melizmatu. Za sprawą zastosowania znaku pauk $\backslash$ doszło do przeniesienia akcentu na trzecią sylabę, co w pełni odpowiada tekstom zawartym w Oktoichach ${ }^{40}$ nie posiadającym nut. Fragment wieńczy melizmat kulizma s'riedniaja, który dla każdej z ośmiu skal modalnych posiada odrębną melodię. Wyjątek stanowią śpiewy tonów 2 i 6 , gdzie melodia kulizmy s'riedniej jest uzależniona od miejsca, w którym ona występuje. Tak więc, jeśli formuła znajduje się w środku melodii/końcu frazy melodycznej, wówczas kulizma s'riedniaja posiada inną melodię, niż w przypadku, gdy znajduje się na końcu danej kompozycji.

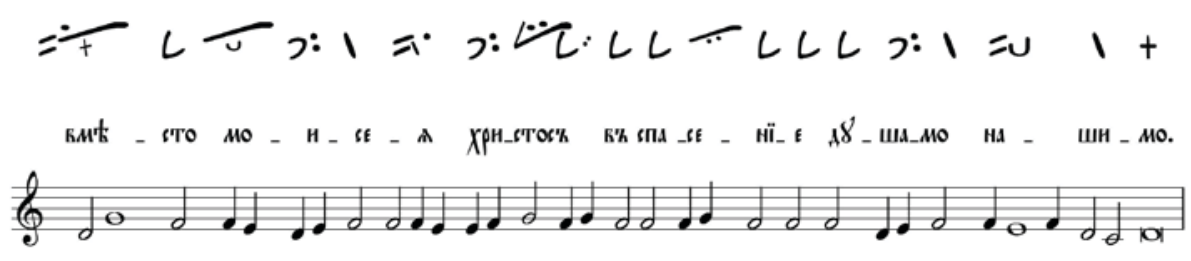

Mojżesz przepowiedział przyjście na ziemię Mesjasza, jako proroka podobnego sobie, a jednocześnie sam był praobrazem Chrystusa. W osobie Mojżesza łączą się dwie główne prerogatywy, a mianowicie jako prawodawcy i wodza narodu. Nic dziwnego, że Żydzi upatrywali w Mesjaszu proroka podobnego Mojżeszowi. Natomiast Jezus Chrystus okazał się prorokiem wyższym od innych proroków, wodzem wiodącym wierzących w Niego ku zbawieniu. Treść dogmatyków, w szczególności dogmatyka tonu drugiego, inspirowała pisarzy kościelnych pierwszych wieków chrześcijaństwa na Rusi. Dobrym przykładem jest Opowieść o stanie mniszym, o Starym i Nowym Testamencie (Zakonie), z (których) jeden nosi w sobie obraz (drugiego), zaś (drugi) dopetnia jego czynów autorstwa Cyryla z Turowa. Utwór ten nie posiada jednolitej struktury, ani także ramowej fabuły, co niejako utrudnia

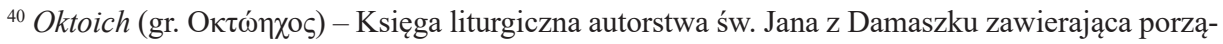
dek nabożeństw na niedziele i dni cyklu tygodniowego rozdzielonego w ciągu roku według ośmiu tonów (cs. głasow). Z biegiem czasu w skład Oktoicha weszły stichery ewangeliczne, których autorstwo przypisuje się Leonowi Mądremu - synowi Aleksandra Macedończyka. Z czasem utrwalił się współcześnie znany podział Oktoicha na Mały i Wielki. Zob.: арх. Модест, О иерковном октоихе, Вильна 1865, s. 59-77, por. Д. РАзумовский, Богослужебное пение Православной Греко-Российской Церкви. Москва 1886, s. 32.
} 
jego analizę ${ }^{41}$. Niemniej jednak w jednym z rozdziałów, zatytułowanym ,, $a$ w Miejsce Mojżesza Chrystus”, Cyryl z Turowa pisze: „Jeśliby Chrystus nie złożył Ojcu ofiary za grzeszników, oczekując naszej pokuty; wówczas słabościami byśmy nie odziedziczyli obiecanego nam Królestwa Niebieskiego" ${ }^{\text {22 }}$.

Fragmentowi, odnoszącemu się do Mojżesza, staroruski kompozytor dogmatyka tonu drugiego przyporządkował prostą kombinację formuł melodycznych, tj. strietu mracznuju łomkoju wwierch =- †oraz statii zakrytoj s'riedniej, która niekiedy utożsamiana jest z melizmatem fotiza. Pisownia pierwszej neumy w czasie powstania Irmologionu Ławrowskigo oraz w okresach poprzedzających w zasadzie nie różni się od striety połukryżewoj, której zasady wykonania są bardzo zbliżone, a w przypadku późniejszych redakcji dogmatyka tonu drugiego niemal identyczne. Analiza porównawcza omawianego fragmentu, zawartego w Irmologionie Eawrowskim oraz w powstałym kilkadziesiąt dni później Irmologionie Supraskim (1598-1601) B. Onisimowicza, odkryła pewne różnice w redakcji. Otóż pisownia omawianego fragmentu z Irmologionu Ławrowskiego, a co za tym idzie także melodyka nie odbiega od późniejszych zabytków pisanych staroruską notacją kriukową.

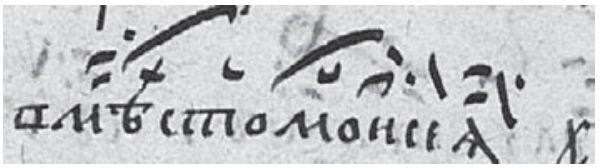

BN, 12050 ( Akc 2954), k. 209.

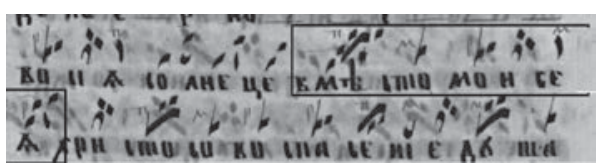

Ирмолой и Октай, zb. pryw. DS, k. 137.

Rysunek 4.

Natomiast redaktor Irmologionu Supraskiego (1598-1601) - B. Onisimowicz we fragment traktujący o Mojżeszu wplótł rozbudowaną frazę melodyczną. W podobnym kierunku poszedł dalszy rozwój melodii dogmatyka tonu drugiego, czego dobrym przykładem jest datowany na 1630 r. Irmologion z Bruślinowa.

\footnotetext{
${ }^{41}$ G. PodsKalsky, Chrześcijaństwo i literatura teologiczna na Rusi Kijowskiej (988-1237), Kraków 2000, s. 220.

${ }^{42}$ Кирилл Туровский, Сказание о черноризьчьстьмь чину, ошъ Вьтхаго закона и Новаго, оною образъ носяіия, а сего дъды съвьршающа, w: Памятники Российской Словесности ХІІ века, Москва 1821, s. 108.
} 


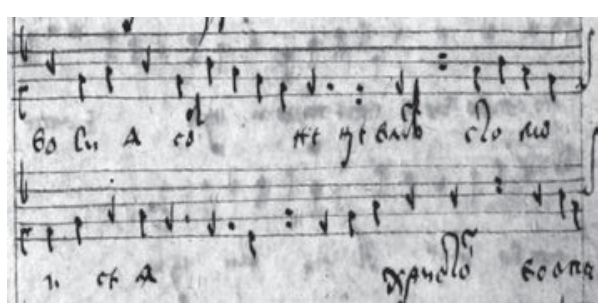

НБУВ, I, 5391, k. 232.

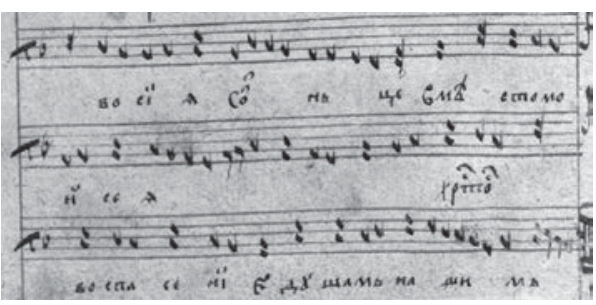

BBN, 12055 I (Akc. 2932), k. 6.

Rysunek 5.

Kompozycję dogmatyka tonu drugiego wieńczy kulizma s'riedniaja końcowa, która występuje zarówno w melodiach tonu drugiego, jak i szóstego. Poprzedzona dynamicznym wprowadzeniem $>$ : । formuła posiada typową dla omawianego okresu pisownię, na którą składają się połukulizma $=u$, pałka oraz znak kończący melodię, tj. kryż + .

Reasumując, cechą charakterystyczną melodii dogmatyka tonu drugiego jest cykliczna powtarzalność kilku następujących po sobie formuł melodycznych, w szczególności popiewek i fity. Z tego względu należy przyznać pełną rację ukraińskiej badaczce tematu O. Całaj-Jakymenko, jakoby omawiana melodia dogmatyka tonu drugiego posiadała strukturę periodyczną ${ }^{43}$. Struktura ta praktycznie nie uległa zmianie do dnia dzisiejszego i jest świadectwem głębokiego zakorzenienia omawianej melodii w tradycji śpiewu liturgicznego Rusi Kijowskiej. Mimo to sposób jej zapisywania, a wraz z wprowadzeniem do piśmiennictwa muzycznego na południowo-zachodniej Rusi ulegał stałej ewolucji, podobnie jak wśród śpiewaków różnych epok zmieniało się postrzeganie skali dźwiękowej, czego dobrym przykładem są pochodzące z Południowego Podlasia Irmologiony z Rokitna i Witoroża.

Mam nadzieję, że poruszona w niniejszym opracowaniu problematyka stanie się impulsem do dalszych badań nad staroruskim śpiewem cerkiewnym i jego funkcjonowaniem na terytorium południowo-zachodniej Rusi, a także Południowego Podlasia.

\section{BIBLIOGRAFIA}

Źródła:

Irmologion Ławrowski (2. poł. XVI w.), BN, sygn. Rps 12050 ( Akc 2954).

Irmologion Supraski (1598-1601), ЦНБ, sygn I, 5391.

${ }^{43}$ О. ЦАЛАЙ-ЯкИМЕНКО, Київська школа, s. 117. 
Азбука певчая, ККГУНБ, № 76647.

Ирмолой и Октай, (2. poł. XVIII w., Zbiory prywatne Daniela Sawickiego).

Октай (XIX w. Zbiory prywatne Daniela Sawickiego).

Мезенец А., Извещение о согласнейших пометах, (rps 1. poł. XIX w. Zbiory prywatne Daniela Sawickiego).

Irmologion z Bruślinowa (1630 r.), BN, 12055 I (Akc. 2932).

Irmologion z Rokitna (2. poł. XVII w.), KUL, Rkp 387.

Irmologion z Witoroża (2. poł. XVIII w), KUL, Rkp 391.

Азбука певчая, НИОР РГБ, zеsp. 173. III., nr 151.

\section{Opracowania:}

ABIJSki M., Bogdan Onisimowicz - śpiewak rodem z Pińska, w: Latopisy Akademii Supraskiej, t. 1: Prawosławni w dziejach Rzeczypospolitej, Białystok 2010, s. 49-58.

Podskalsky G., Chrześcijaństwo i literatura teologiczna na Rusi Kijowskiej (988-1237), Kraków 2000.

SAWICKI D., Ciagłość tradycji staroruskiej monodii cerkiewnej na przykładzie wybranych dogmatyków ośmiu skal modalnych z Irmologionów Eawrowskiego i Supraskiego „Wschodni Rocznik Humanistyczny" [Lublin-Radzyń Podlaski], 15(2018), nr 1, s. 23-50.

SAwICKI D., Nauczanie staroobrzędowców pomorskich w kwestiach odnoszacych się do śpiewu cerkiewnego, ELPIS 2017, t. 19, s. 67-78.

SAwICKi D., Staroje istinnorieczije i razdielnorieczije jako dwie główne epoki w dziejach śpiewu liturgicznego na Rusi od XI w. do XVII w., w: Z badań nad językiem i kultura Stowian, red. P. Sotirov, P. Złotkowski, Lublin 2007, s. 169-178.

SAwICKI D., Staroruski neumatyczny Irmologion Ławrowski z XVI wieku - niezbadany zabytek wschodniostowiańskiego piśmiennictwa muzycznego na poludniowo-zachodniej Rusi, „Wschodni Rocznik Humanistyczny" [Lublin-Radzyń Podlaski], 13(2016), s. 18-56.

SAwICKi D., System formuł melodycznych staroruskiego śpiewu cerkiewnego na przykładzie dogmatyka tonu pierwszego z XVI-wiecznego Irmologionu Ławrowskiego, ,Wschodni Rocznik Humanistyczny" [Lublin-Radzyń Podlaski], 16(2017), nr 1, s. 7-28.

SAwICKI D., Z badań nad śpiewem cerkiewnym na Poludniowym Podlasiu w XVIII-XIX w. Irmologiony z Rokitna i Witoroża, „Rocznik Bialskopodlaski” [Biała Podlaska], 24(2016), s. 89-117.

Wereda D., Unicka diecezja włodzimiersko-brzeska (część brzeska) w XVIII w., Siedlce 2014.

WoŁosiuk W., Irmologion Supraski, „Rocznik Teologiczny” [Warszawa], 46(2004), nr 2.

Znosko A., Słownik cerkiewnosłowiańsko-polski, Białystok 1996.

АлексеЕва Г., Византино-русская певческая палеография, Санкт-Петербург 2007.

Борзецовский С., Объяснение догматиков восьми гласов, Москва 1878.

БРАЖНИКОВ М., Лииа и фиты знаменного распева, Ленинград 1984.

ВЛАдЫШЕвСКАя Т., Музыкальная культура древней руси, Москва 2006.

ГерцмАн Е., Византийское музыкознание, Ленинград 1988.

Григорьев Е., Пособие по изучению иерковного пения и чтения, Рига 2001.

Кручинина А, Попевка знаменного роспева в русской музыкальной теории, w: Певческое наследие Древней Руси (историа, теория, эстетика), Санкт-Петербург 2002, s. 46-150.

Кручинина А., О семиографии попевок знаменного роспева в музыкально-теоретических руководствах нониа XV - середины XVII века, w: Проблемы истории и теории древнерусской музыки, сост. А Белоненко, Ленинград 1979, s. 148-159.

Лозовая Е., Столповой знаменный распев (2-я половина (XV-XVII вв.) Формульная структура, Москва 2015.

Мартынов В., История богослужебного пения, Москва 1994. 
Металлов В., Азбука крюкового пения. Опыт систематического руководства к чтению крюковой семиографии песнопений знаменного роспева, периода киноварных помет, Москва 1899.

Модест арх., О иерковном октоихе, Вильна 1865.

РАзумовский Д., Богослужебное пение Православной Греко-Российской Церкви. Москва 1886, s. 32.

РАзумовский Д., Церковное пение в России, Москва 1867-1869.

Туровский Кирилл, Сказание о черноризьчьстьль чину, ошъ Вьтхаго закона и Новаго, оною образъ носяіия, а сего дъды съвьриающа, w: Памятники Российской Словесности ХІІ века, Москва 1821.

УСПенский Б., К вопросу о хомовом пении w: Музыкальная культура средневековья, Вып. 2 (Тезисы и доклады конференций), Москва 1991.

Флоринский Н., История богослужебных песнопений Православной Кафолической Восточной Церкви, Kijów 1881.

ЦАЛАй-ЯкИменко О., Київська школа музыки XVII століття, Київ-Львів-Полтава 2002.

ШАБАЛИн Д., Певческие азбуки Древней Руси, t. 1, Краснодар 2003.

Яспновський Ю., Ірмоси Київької Церкви. Критичне видання за супрасльским нотолінійним ірмологіоном 1598-1601 років, t. 2, Львів 2018.

Ясіновський Ю., Супрасльский ірмолой Богдана Онисимовича як пам'ятка київської митрополії, ,КАИОФ $2 N I A ” 2016$, nr 8, s. 46-88.

\section{ROZWÓJ FORMUŁ MELODYCZNYCH W STARORUSKIEJ MONODII CERKIEWNEJ NA PRZYKŁADZIE DOGMATYKA TONU DRUGIEGO NA PODSTAWIE WYBRANYCH ZACHODNIORUSKICH IRMOLOGIONÓW XVI-XVIII W.}

$$
\text { Streszczenie }
$$

W artykule autor dokonał analizy formuł melodycznych zastosowanych w dogmatyku tonu drugiego. W tym celu posłużył się wybranymi Irmologionami, zarówno tymi najstarszymi, pochodzącymi z terytoriów dzisiejszej Białorusi i Ukrainy, jak również śpiewnikami pochodzącymi z cerkwi unickich Południowego Podlasia, w szczególności Rokitna i Witoroża. Autor wskazuje na istotną rolę prawosławnych monasterów, a po zawarciu Unii brzeskiej (1596 r.) także parafii w rozwoju staroruskiego śpiewu cerkiewnego. W toku prowadzonych badań autor wykazał, iż pomiędzy melodyką dogmatyka tonu drugiego a tekstem zachodzi ścisły związek. Ponadto prowadzone badania ukazały, iż struktura melodii dogmatyka tonu drugiego oraz dobór formuł melodycznych, mimo upływu lat, nie uległy istotniejszym zmianom.

Słowa kluczowe: śpiew liturgiczny Kościoła prawosławnego; muzyka cerkiewna; znamienny śpiew.

\section{THE DEVELOPMENT OF THE MELODIC FORMULAS IN OLD RUTHENIAN ORTHODOX CHURCH MONODY ON THE EXAMPLE OF DOGMATICON OF THE SECOND TONE BASED ON SELECTED $16^{\mathrm{TH}}-18^{\mathrm{TH}}$ CENTURY WEST RUTHENIAN IRMOLOGIONS}

\section{Su m mary}

In the work in question, the author has analysed the melodic formulas used in the dogmaticon of the second tone. For this purpose, the author has used selected Irmologions, both the oldest, which originate from the territories of today's Belarus and Ukraine, and song books originating from the 
southern Podlachia Uniate Orthodox churches, in particular of Rokitno and Witoroże. The author points to the important role of the Orthodox monasteries and, after the signing of the Union of Brest (1596), also to that of the parish, in the development of the Old Ruthenian Orthodox church singing. In the course of the research, the author has proven a close connection between the dogmaticon of the second tone melodics and the text. Moreover, the conducted research has shown that, despite the passage of time, there has been no change in the structure of the dogmaticon of the second tone and in the selection of the melodic formulas.

Key words: liturgical singing of the Orthodox Church; Orthodox church music; znamenny chant. 